\title{
Ancient Manuscript Preservation of Museum Ranggawarsita Library Collection Semarang Central Java
}

\author{
Khafidlin \\ Universitas PGRI Semarang, Indonesia
}

Article Info

Received April 1, 2021

Revised April13, 2021

Accepted April 19, 2021

Keywords

- Ancient manuscripts

- Preservation

- Preventive measures

- Curative measures

\section{Abstract}

Introduction: This article "Ancient Manuscript Preservation of Museum Ranggawarsita Library Collection Semarang Central Java" aims to determine the types of ancient manuscripts, damage factors, preservation procedures, obstacles encountered, and the appropriateness between theory and application.

Methods: This study used a data collection include library research, observation and interviews, while the data processing method uses descriptive analysis.

Results and discussion: The results show is a Ranggawarsita Museum Library differentiates its ancient manuscripts into two types: the original manuscript (hand) or in other words, in the form of strips of palm leaf manuscripts, totaling 15 titles and texts that have been experienced over the media in the form of typed writing, totaling 100 titles and the age is 50 years. Damage was generally caused by climatic factors, namely temperature and humidity, pollutant gases, dust and insects. Handling was done by means of preventive measures, curative, control of temperature and humidity, dust, treatment and restoration. Obstacles encountered were environmental conditions near the highway, so a lot of gas pollutants from motor vehicles, the limited budget and space.

Conclusion: Applied ancient manuscript conservation activities are in accordance with existing theory that is by controlling the temperature and humidity, dust cleaning, prevention of pollutant gases, insects, preventive measures, curative and restoration. That way the ancient manuscript are still preserved.

\section{Introduction}

Library materials are the result of the nation's culture as evidenced by the issuance of Decree of the President of the Republic of Indonesia No. 11, 1989, of the National Library. The decree states that the library has a fundamental duty to preserve library materials as a result of cultures, perform maintenance and preservation of library materials, implement storage and preservation of national and international publications, both printed and recorded and implement conservation.

The manuscripts constitute our most precious national and cultural heritage (Sahoo \& Mohanty, 2008). Thus Preservation of manuscripts is a serious issue for the custodians, Librarians, Information scientists, Archivist, Curators, and Scholars. In spite of the advent of suitable chemicals for preservation and their availability, traditional methods for preservation are in practice.

Preservation of library materials as a result of the culture of which is an ancient manuscript contains a variety of ideas, knowledge, customs, as well as the behavior of past societies. According to the understanding contained in the Ordinance Monumentum

\footnotetext{
* Corresponding author.

Email address: elkha.murdhowo@gmail.com
} 
Gazette 238/1931, which meant codex or longer is fabricated in the form of handwritten or typewritten fifty years old, are being referred to the old books are fabricated in the form of a printed book that has aged five twenty years (Mandra, 1992).

Manuscripts are the primary sources of our culture and tradition. The collection of manuscripts is available all over the maximum part of the country. Today, most of them face many problems due to many reasons, in the past we have also lost a big number of manuscripts due to lacking of awareness. Manuscripts cannot survive without proper care, so it is our duty to conserve and preserve those manuscripts, save for the next generation (Mahawar \& Kuriya, 2013)

According to Law No. 43 of 2007 includes general provisions of Article 1 point 4 mentions "manuscripts are all written documents that are not printed or reproduced in any other way, both inside and outside the country are owned by libraries in the territory of the unitary state of Indonesia".

After the invention of writing media, the scholars stored their knowledge in various media such as stone, wood, leather or in the form of manuscripts like papyrus, parchment, palm leaf, vellum and paper, which are the primary sources of the traditional knowledge in the present era. It is our responsibility to preserve them and to save for the next generation, because the ancient valuable resources symbolize our significance of culture and tradition, which describe the history of the development of earlier civilization. The invention of writing media, handmade Paper was the very important media for storage the information in the earlier time, handmade paper dominated in every area of the life. Most of the earlier information/knowledge is available in the form of handmade paper manuscripts, which are stored in the museum, library, temple and monk. Recently, it is a very serious problem related to conservation and preservation of these valuable resources.

Library and museum have continuously played an important role in the storage and dissemination of knowledge/information. It is a house of knowledge, where knowledge is stored in organized form. Library fulfils the general and special need of users. These seats of learning had a good oriental collection in classical languages. In the medieval period, particularly during the Mughal rule, a large number of madrasas were established which had a rich collection in Persian, Arabic and Urdu languages. In the modern period a large number of institutions, schools, colleges, and universities were set up which possess a collection of oriental literature in addition to resources in modern Indonesian languages.

Codex is the result of the nation's cultural history that needs to be preserved and also protected. Efforts to make the protection stipulated in Law No. 5 of 1992 states "Bringing ancient manuscripts outside Indonesian territory without permission from the government threatened with criminal sanctions as high as 10 years in prison or a maximum fine of 10 million rupiahs". The government's concern to protect the manuscript is realized by establishing institutions that houses the protection and preservation such as libraries and museums.

Ancient manuscript is a powerful medium for the preservation of our literature, linguistics, art and cultural heritage. It is the only unknown source. So, every effort should be made to save this treasure for future generations.

As an institution that protects objects of cultural heritage, it is proper for Library of Ranggawarsita Museum to perform the functions, duties and responsibilities for the preservation of ancient manuscripts result of cultural heritage that needs to be saved, either physical form or information. Based on the description above, this article will discuss the Preservation of Ancient Manuscripts Collection in Library of Ranggawarsita Museum, Semarang, Central Java which includes factors that cause damage to library materials and procedures for the preservation of library materials. 


\section{The concept of Ancient Manuscript Preservation.}

Text is original essay; paper to be published; letter of agreement (for cooperation), ancient is classic, old-fashioned (goods); old-fashioned; orthodox; primitive; (from) time immemorial. Based on the materials used, the script can be classed among others, 1) manuscripts written on paper and bones, 2) manuscripts written on palmyra palm, 3) manuscripts written on palm leaves, 4) text written on wood, 5) manuscripts written on bamboo, 6) manuscripts written on rattan (Partanto \& Albarry, 1997). Codex is a cultural creation which is handwritten on the media such as palm leaves, palm leaf, papyrus, bone, cloth, horn, rattan, bamboo, bark and European paper, containing the history, folklore, tale, art and culture, religion, traditional medicine, agriculture, law, customs and others at least 50 years old are stored in a library or museum (Plenderleith, 1956).

Preserving codex is an activity that needs to be done by the government and society, so that the script can be learned and used from the value of the information by the next generation. The durability of collection consisting of paper material and non-paper materials should be maintained. According to Robson (Lubis, 1996) few libraries in the world have thousands of manuscripts written in a local language with materials of diverse writings. The manuscripts were kept well, but it was not enough, because they ultimately will be destroyed manuscript and not necessarily able to be saved by using a photo or microfilm. Among other factors that cause damage to physical factors, biological factors, factors of chemical compounds, and other factors. Physical factors include temperature and air humidity and light. Biological factors include rodents, termites, moths clothing, and fungi. Factors include the chemical compounds of sulfur dioxide gas, and damage due to ink. Other factors include human and natural disasters.

Taking care of library materials seems simple, but when associated with human as one of the causes of damage, then the job is not simple. The procedure which is done to protect the preservation of library materials is preventive conservation, determination of the type and condition of library materials, conservation and restoration, knowing the stage of conservation treatment, lamination, encapsulation, microfiche, dust cleaning and fumigation.

\section{Methods}

The methods used in data collection include library research, observation and interviews. The literature study method is a series of activities related to the method of collecting library data, reading and taking notes, and processing research materials (Zed, 2004). Observations by researchers were carried out by coming directly to the Ranggawarsita Museum and making direct observations which were dulled by museum officers. Meanwhile, researchers conducted interviews with experts in the preservation section, while the data processing method used descriptive analysis. The object is Library Museum research Ranggawarsita Semarang, Central Java.

\section{Discussion}

Old manuscripts are usually stored in safe places in museums and libraries, and can be known through various available catalogs. As it was done, the Library of Ranggawarsita Museum has already done an inventory of ancient manuscripts in the collection of the library. Source codex comes from the purchase. Ancient manuscripts in the Ranggawarsita Museum Library are collection of objects of cultural heritage that needs to be protected for conservation. The Library of Ranggawarsita Museum distinguished ancient manuscript 
collections into two types, namely, 1) the original manuscript (hand) or in other words, in the form of draft texts palm strips that are 15 titles. 2) the script had undergone a rewriting or typewriting media totaling over 100 titles and age was 50 years.

Papyrus manuscripts were written in Java (ancient and new Java), 50 years old manuscript, describing philosophy, literature and religion. Etymologically, Lontar comes from the Javanese language Ron and Tal. Ron means leaf and Tal means siwalan Ancient manuscripts in the Library of Ranggawarsita Museum were placed on vitrin, separated from other library materials, due to anticipation of more severe damage due to environmental and human factors.

\subsection{Causes of Damage}

Factors causing damage to library materials codex Ranggawarsita Museum Library collection are divided into two, namely intrinsic and extrinsic factors. Intrinsic factors are factors that the damage stems from the object itself, such as the quality of the paper, the effect of ink, the type of paper which is made from a mixture of materials containing chemical elements and because of the chemical process, the paper will continue to change and damaged. Extrinsic factors are factors that the damage comes from outside the body.

\subsection{Damage due to factors Physics}

Temperature and humidity. Temperature and humidity are one of the causes of damage to library materials in the Library Museum Ranggawarsita. The ideal temperature for storage of library materials ranging from 20C-24C. Libraries can also set the room temperature of the storage of library materials and a user space of library materials. Low temperature storage of library materials revolves around 10C, but should not be too low or too high. If the temperature is too low, it will result in cracked raised pattern on papyrus manuscript collections.

Gas pollutants. Gas pollutants from motor vehicles will produce sulfur dioxide gas. due to the presence of metal particles on the paper and the air that can act as a catalyst, the sulfur dioxide gas will be oxidized to sulfur trioxide gas. This gas can react with water vapor producing sulfuric acid which is very dangerous for library materials.

Dust. Dust and dirt can cause stains and unclear writing and can obscure the content of writing. Surface dust and dirt on the surface of library materials can cause stains in wet conditions because the air is humid, facilitating mold spores attached on the surface and $t$ to thrive when environmental conditions allow. Dust and dirt can be metallic particles, carbon, sulfur dioxide gas and oily materials such as oil, petroleum jelly, which is very dangerous for library materials.

\subsection{Damage due to factors Biology}

Fungi. Fungi are one of the causes of damage to library materials source of organic material such as ancient manuscripts. In addition to its age that old manuscripts is susceptible to damage, fungus can also cause damage. The emergence of the fungus may be affected due to factors including the climate and humidity experienced by the majority Ranggawarsita Museum Library collection damaged caused by the fungus.

Termite. Termites are insects causing damage to library materials. Termites are one of the most dangerous insects for library materials because it can damage library materials in a short time. These animals live in the tropics and subtropics. There are two types of termites, dry termites that live in wood (wood dwellers) and termites that live in the soil 
moist. Termites are one of the factors causing damage to the continuation of the preservation of library materials either in the library or in a museum.

Rat. Rats are vermin to library materials of Ranggawarsita Museum Library. Rats attack on objects made of wood, such as library materials storage cupboard where ancient manuscripts are placed. The result would undermine the existing collection. The efforts to avoid damage from these animals that were conducted by conservation officers are keeping the room clean, especially in the storage of library materials made from organic, which is placed in the study chamber and preservation, giving an anti-rat in the room of library of ancient manuscripts to repel rodents from the room.

Moth. Moth is an insect that can break the library materials. These insects attack the organic material library materials such as paper and leather. These insects with thin body and brown colored skin prefer to live in the dark.

\subsection{Damage due to Other Factors}

It is damage by human factors caused by incorrect use or not in accordance with the procedure. The purpose of using it here is not in accordance with procedures such as holding the script, opening a script that is too rough, as a result the manuscript becomes torn. Old and brittle manuscripts is very susceptible to damage caused by humans if not handled carefully. In addition to the use of the human factor in the damage caused can also be caused due to an error in conservation because of negligence.

\subsection{Ancient Manuscript Preservation Procedures}

Ranggawarsita Museum Library as an institution that shelters and protects cultural heritage objects has carried out its function by carrying out preservation carried out by expert staff of assessment and preservation. The preservation carried out by the Ranggawarsita Museum Library has fulfilled the following procedures,

Preventive conservation that is a efforts to protect library materials of pollutant gases, then the library space should use air purifier filters (air cleaner) to clean the air that goes into the library. Library building should be made of fire-resistant materials, anti-insect, and the walls of the building to cover the possibility of capillary walls into the ground water. This plan has been carried out by the Library Museum Ranggawarsita since the beginning of the construction of the building in anticipation as mentioned above. The building is still undergoing renovation of buildings that are considered important in order to save the collections of both of damage or theft.

Curative. Curative or prevention is the treatment done when the collection has undergone weathering by means of restoration, cleaning mildew and application of insecticidal materials.

Dusting. Dusting is one way of conservation Ranggawarsita Museum Library in conducting preservation of library materials in the library. This is done in order to avoid further damage to library materials due to the location of the Museum Ranggawarsita which is close to the highway. Almost certainly the dust will always come and stick to library materials. Dust cleaning done once a week.

Fumigation. Fumigation is a method used by the Library Museum Ranggawarsita in the rescue of the objects from the museum's collection which are made from damage of both organic and non-organic as library collections of ancient manuscripts in the form of palm leaves, material library book 50 years of age and also other objects. Fumigation is done to prevent the damage caused by fungi and insects. 
Fumigation steps in Library Museum Ranggawarsita are, 1) Checking the indoor blower fumigation whether it is operational or not. 2) Checking the rubber seal on the door fumigation of the chamber, making sure that the door is closed so the gas will not be able to get out. 3) Preparing a container made of plastic or glass. 4) Inserting and managing library materials that will be fumigated. Library materials such as books and paper sheets shall be arranged properly so that the fumigant can enter between the papers. Thick hardback book is placed standing on a shelf with a V-shaped position, reclined or reversed, while the library materials that cannot stand up can be mounted with the plastic strap above the spine. 5) Wearing protective equipment such as masks, headgear and gloves. 6) The chemicals used for fumigation is thymol solution and ethanol in the ratio 150gr 1lt thymol and ethanol.

Handling. Handling is one of preservation which is done in the Library Museum Ranggawarsita. Handling is more focused on workmanship, handling the preservation of a technical nature.

\subsection{Constraints of Implementation}

Constraints that have been faced by the Library Museum Ranggawarsita in conservation activities, such as:

Environmental conditions and climate. The location of the library near the highway is a constraint faced in doing conservation. Air pollutants such as pollutant gases, dust and metal particles in the air can lead to library. Materials which are made from organic materials that have been damaged, fragile and old will be more severe if no immediate action is taken to take care ancient manuscripts that became one of the Library's collections Ranggawarsita Museum.

Gas pollutant or pollutants. Ideally, the location of the library should not be located in the industrial area or a populated area by motor vehicle, because the industry and motor vehicles emit pollutant gases such as SO and NO gas that are harmful to library materials.

Budget. Budget is a classic problem yet it is also vital because the preservation requires substantial funds. Preservation cannot be done manually, but requires support tools to protect library materials that have been damaged to be utilized as source of information. These constraints also are factors in the Library Museum Ranggawarsita in preservation of the objects collection. Preservation budget allocated once a year.

Room. The rooms were not using the AC (air conditioner) becoming an obstacle for Ranggawarsita Museum Library. Using the AC would be better because it is useful to control the humidity in the room. Good air humidity is around $50-60 \%$ and a temperature of about $60-75^{\circ} \mathrm{F}$ or $22-25^{\circ} \mathrm{C}$. There is a filter for the air conditioner as an air filter. So, it is good if the library is doing it, especially on the part or space where conservation is important.

\section{Conclusion}

Preservation of Library Museum Ranggawarsita Semarang Central Java is an activity related to the maintenance of museum objects so that they are durable and not easily damaged and can be used both materially and value information. Preservation procedures done by way of prevention of damage to library materials caused by factors biology, physics, chemistry, other factors such as human error and natural disasters, treatment, repair, preventive and curative measures. 
References

Lubis, N. (1996). Naskah, teks, dan metode penelitian filologi. Forum Kajian Bahasa \& Sastra Arab, Fakultas Adab IAIN Syarif Hidayatullah.

Mahawar, K. L., \& Kuriya, M. K. (2013). Conservation and Preservation of Manuscripts in the Saulat Public Library Rampur, Uttar Pradesh. : A Survey and Proposal for their Modernization. International Journal of Humanities and Social Science Invention ISSN (Online, 2(3), 2319-7722.

Mandra, A. M. (1992). Lontar Mandar. Kementerian Pendidikan dan Kebudayaan Direktorat Jenderal Kebudayaan Direktorat Sejarah dan Nilai-nilai Tradisional serta Proyek Penelitian Pengkajian Nilai Kebudayaan Nusantara.

Partanto, P. A., \& Albarry, M. D. (1997). Dictionary of Popular Science. Arkola.

Plenderleith, H. . (1956). Conservation of Antiquities and Works of Art. London Oxford University Press University Press.

Sahoo, J., \& Mohanty, B. (2008). Indigenous Methods of Preserving Manuscripts: an overview. The Orissa Historical Research Journal, XLVII(3), 28-32. http://magazines.odisha.gov.in/Journal/journalvol3/Journal.htm

Zed, M. (2004). Metode Penelitian Kepustakaan. Yayasan Obor Indonesia. 